\title{
Natural Resources of Tourism: Towards Sustainable Exploitation on a Regional Scale
}

\author{
Dmitry A. Ruban
}

check for

Citation: Ruban, D.A. Natural Resources of Tourism: Towards Sustainable Exploitation on a Regional Scale. Sustainability 2021, 13, 6685. https://doi.org/10.3390/ su13126685

Received: 9 June 2021

Accepted: 11 June 2021

Published: 12 June 2021

Publisher's Note: MDPI stays neutral with regard to jurisdictional claims in published maps and institutional affiliations.

Copyright: (C) 2021 by the author. Licensee MDPI, Basel, Switzerland. This article is an open access article distributed under the terms and conditions of the Creative Commons Attribution (CC BY) license (https:/ / creativecommons.org/licenses/by/ $4.0 /)$.
K.G. Razumovsky Moscow State University of Technologies and Management (The First Cossack University), Zemlyanoy Val Street 73, 109004 Moscow, Russia; ruban-d@mail.ru

\section{Introduction}

Modern tourism studies focus largely on sociological perspectives on tourist activities [1-5] and environmental aspects of tourism development [6-10]. In other words, tourism is considered as a social phenomenon with an evident ecological impact. However, such a vision is somewhat biased, because tourism itself is impossible without a valuable resource basis, and natural resources are often vital for tourism development on a given territory. These ideas have become especially clear together with the rise of such an innovative, nature-dependent direction of tourism as geotourism in the 2010s [11-17].

A vast amount of knowledge on the natural resources of tourism, i.e., natural objects, systems, landscapes, processes, and events, which can be employed for the purposes of tourism development, has been accumulated, but this knowledge is often neglected as something too obvious. The relevant publications are not so infrequent, but these often appear in 'marginal' and even difficult-to-access scientific media. Evidently, this situation is challenging. There are many 'fresh' examples demonstrating how a correct understanding of natural resources, their localization, and their true value facilitates tourism growth and contribute to sustainable development in particular geographical loci-countries, regions, and natural domains [18-22].

The natural resources of tourism constitute a very broad category, and their diversity has to be addressed. They can be classified depending on the dominant and most useful (to tourists) landscape elements. If so, geomorphological (landforms), geological (minerals, rocks, and fossils), hydrological (rivers, lakes, and seas), and biological (animals and plants) resources should be distinguished. The natural resources of tourism can also be classified depending on their functionality. They are related to tourism, recreation, hospitality, and infrastructure, and these can be used either directly or indirectly. Finally, it is possible to classify the natural resources of tourism depending on their state. They can be judged static and dynamic, as well as physical, culturally-interpreted, and aesthetic. Undoubtedly, these tentative classifications need further improvements and justifications to become more universal, which is an important task for further investigations.

Our understanding of the natural resources of tourism depends on the analytical depth and geographical breadth of the relevant research. Well-performed case studies of various aspects of the natural resources of tourism in different places of the world are required in order to improve this understanding and to make it really adequate. Tourism studies are not only about tourists, hotels, and transport. Attractions that allow tourism growth need to be carefully inventoried, and their useful properties must be revealed, to determine the tourism potential of each given object. In the case of tourism's natural resources, such studies become often inter- or even multidisciplinary because they require the involvement of experts from several branches of science, including biologists, geographers, archaeologists, etc., as well as economists, sociologists, and, indeed, tourism experts. 


\section{Volume Overview}

This special issue focuses on the characteristics of the various natural resources of tourism. Its main purposes are (1) to provide examples from very different places of the world, (2) to clarify the possibility of exploiting these resources for the purposes of the tourism industry, and (3) to focus on the regional dimension of nature-based tourism development and governance. In this special issue, a broad understanding of regions is allowed, i.e., these can be geographical domains, provinces of any country, or geopolitical macroregions (depending of the preferences of the contributing experts). Special attention is paid to how natural resources can contribute to the sustainable development of tourism on a regional scale. In other words, this special issue is nothing less than an attempt to make the contemporary tourism science more resource- and region-focused.

The contributions to this special issue address the above-mentioned purposes, and the proposed tasks are achieved in very different contexts. Taken together, these contributions reveal the complexity of the idea of tourism's natural resources and put it into a multidimensional framework. Below, the content of this special issue is briefly explained, and a logical arrangement of the contributions is undertaken (Table 1). In order to accomplish the latter, the 14 contributions are assigned to four main themes, namely geotourism resources, rural versus urban resources, recreational resources, and natural resources in tourism networks.

Table 1. Logically arranged content of this special issue.

\begin{tabular}{|c|c|c|}
\hline Number & Contribution & Geographical Focus \\
\hline \multicolumn{3}{|c|}{ Theme 1: Geotourism Resources } \\
\hline I. & $\begin{array}{l}\text { Afrasiabian, A.; Sivan, S.M.; Dogančić, D.; Plantak, L.; Đurin, B. Geological Features for } \\
\text { Geotourism in the Zanjan and Hamadan Area, Northern Iran. Sustainability 2021, 13, } 6587 .\end{array}$ & Iran \\
\hline II. & $\begin{array}{l}\text { Čech, V.; Chrastina, P.; Gregorová, B.; Hronček, P.; Klamár, R.; Košová, V. Analysis of } \\
\text { Attendance and Speleotourism Potential of Accessible Caves in Karst Landscape of } \\
\text { Slovakia. Sustainability 2021, 13, 5881. }\end{array}$ & Slovakia \\
\hline III. & $\begin{array}{l}\text { Herrera-Franco, G.; Montalván-Burbano, N.; Carrión-Mero, P.; Jaya-Montalvo, M.; } \\
\text { Gurumendi-Noriega, M. Worldwide Research on Geoparks through Bibliometric Analysis. } \\
\text { Sustainability 2021, 13, } 1175 .\end{array}$ & international \\
\hline IV. & $\begin{array}{l}\text { Herrera-Franco, G.; Carrión-Mero, P.; Alvarado, N.; Morante-Carballo, F.; Maldonado, A.; } \\
\text { Caldevilla, P.; Briones-Bitar, J.; Berrezueta, E. Geosites and Georesources to Foster } \\
\text { Geotourism in Communities: Case Study of the Santa Elena Peninsula Geopark Project in } \\
\text { Ecuador. Sustainability 2020, 12, } 4484 .\end{array}$ & Ecuador \\
\hline V. & $\begin{array}{l}\text { Mirari, S.; Aoulad-Sidi-Mhend, A.; Benmlih, A. Geosites for Geotourism, Geoheritage, } \\
\text { and Geoconservation of the Khnefiss National Park, Southern Morocco. Sustainability } \\
\text { 2020, 12, 7109. }\end{array}$ & Morocco \\
\hline VI. & $\begin{array}{l}\text { Štrba, L.; Kolackovská, J.; Kudelas, D.; Kršák, B.; Sidor, C. Geoheritage and Geotourism } \\
\text { Contribution to Tourism Development in Protected Areas of Slovakia-Theoretical } \\
\text { Considerations. Sustainability 2020, 12, } 2979 .\end{array}$ & Slovakia \\
\hline \multicolumn{3}{|c|}{ Theme 2: Rural versus Urban Resources } \\
\hline VII. & $\begin{array}{l}\text { Baek, J.; Kim, Y.; Kim, H.; Song, H. Understanding Visitors at an Urban Park by Profiling } \\
\text { of Destination Attributes. Sustainability 2021, 13, } 4036 .\end{array}$ & South Korea \\
\hline VIII. & $\begin{array}{l}\text { Ermolaev, V.A.; Yashalova, N.N.; Ruban, D.A. Cheese as a Tourism Resource in Russia: } \\
\text { The First Report and Relevance to Sustainability. Sustainability 2019, 11, } 5520 .\end{array}$ & Russia \\
\hline IX. & $\begin{array}{l}\text { Shen, C.; Chang, Y.-R.; Liu, D.-J. Rural Tourism and Environmental Sustainability-A } \\
\text { Study on a Model for Assessing the Developmental Potential of Organic Agritourism. } \\
\text { Sustainability 2020, 12, } 9642 .\end{array}$ & Taiwan \\
\hline $\mathrm{X}$ & $\begin{array}{l}\text { Zagarkhorloo, U.; Heijman, W.; Dries, L.; Batjargal, B. Managing } \\
\text { Herder-Community-Based Tourism: An Institutional Framework for an Integrated } \\
\text { Social-Ecological System. Sustainability 2021, 13, } 4001 .\end{array}$ & Mongolia \\
\hline
\end{tabular}


Table 1. Cont

\begin{tabular}{|c|c|c|}
\hline Number & Contribution & Geographical Focus \\
\hline \multicolumn{3}{|c|}{ Theme 3: Recreational Resources } \\
\hline XI. & $\begin{array}{l}\text { Rodella, I.; Madau, F.A.; Carboni, D. The Willingness to Pay for Beach Scenery and Its } \\
\text { Preservation in Italy. Sustainability 2020,12,1604. }\end{array}$ & Italy \\
\hline \multicolumn{3}{|c|}{ Theme 4: Natural Resources in Tourism Networks } \\
\hline XII. & $\begin{array}{l}\text { Cornejo-Ortega, J.L.; Chávez Dagostino, R.M. The Tourism Sector in Puerto Vallarta: An } \\
\text { Approximation from the Circular Economy. Sustainability 2020,12, } 4442 .\end{array}$ & Mexico \\
\hline XIII. & $\begin{array}{l}\text { Jeong, D.; Choi, E.Y.; Jin, L.; Chon, J. Impact of Spatial Change on Tourism by Bridge } \\
\text { Connections between Islands: A Case Study of Ganghwa County in South Korea. } \\
\text { Sustainability 2019, 11, } 6516 .\end{array}$ & South Korea \\
\hline XIV. & $\begin{array}{l}\text { Kuklina, M.; Trufanov, A.; Bayaskalanova, T.; Urazova, N.; Tikhomirov, A.; Berestneva, O.; } \\
\text { Marukhina, O.; Vidyaev, I.; Fisochenko, O.; Lyzin, I.; Berestneva, E.; Hoch, N. Network } \\
\text { Platform for Tourism Sector: Transformation and Interpretation of Multifaceted Data. } \\
\text { Sustainability 2020, 12, } 6314 \text {. }\end{array}$ & Russia \\
\hline
\end{tabular}

The importance of the first theme, namely geotourism resources, is dictated by its methodological value. Unique geological and geomorphological features constitute an important tourism resource, although its value has been realized relatively recently and its clarity to potential tourists is not always high. Moreover, attention to this resource has been paid more by geologists. As a result of these circumstances, the geotourism-related research has developed, from the beginning, with an emphasis on resource assessment. Apparently, this research stimulates a shift of the international tourism research community towards paying more attention to resources in addition to the sociological and environmental aspects of tourism. This special issue hosts six contributions on geotourism resources, which solve three notable tasks. First, they demonstrate the equal importance of geosites and geoparks to geotourism. Second, they relate geotourism to geoconservation and various types of protected areas. Third, they pay attention to geotourism's benefits to local communities.

The second theme is linked to the importance of natural resources to both rural and urban tourism. Its urgency is determined by the overall high value of tourism to the sustainable development of cities/towns and countryside. Undoubtedly, natural resources can be found and effectively exploited on both rural and urban areas. This special issue hosts four contributions devoted to rural or urban tourism employing natural resources. They solve two particular tasks. First, they explain the role of traditional human-nature interactions in tourism development. Second, they indicate the broad availability of natural elements in rural and urban areas, whose tourism-related use depends partly on public perceptions. More generally, these contributions reveal the presence of a specific resource, which can be termed "nature-rooted resource". It results from modifications or interpretations of products and landscapes with evident natural constituents. This resource seems to be essential for linking tourism and sustainable development.

The third theme is represented by a single contribution of great importance. Evidently, coastal landscapes and their aesthetic properties interpreted by visitors constitute an important natural resource to be used in both tourism sensu stricto and various resort activities. This resource is always under significant anthropogenic pressure and requires preservation. The contribution raises the important question of whether the people (residents and visitors) are ready to cover the costs of this preservation, and it also demonstrates the determinants of the people's willingness-to-pay for the related activities.

Finally, the fourth theme addresses the most complex issues and explains generally the importance of natural resources to the development of tourism networks. This theme is not unexpected because of the high complexity of tourism environments, where each element does not only determine the general meaning of a given environment, but can also trigger changes in this meaning. Moreover, tourism networks create new resources and/or re-elaborate pre-existing resources. This special issue hosts three contributions to this 
theme, and they solve two particular tasks. First, they relate natural resources to the socioeconomic context of tourism. Second, they emphasize the influence of spatial parameters (including spatial connectivity) determined by the natural peculiarities of territories where tourism is growing. Evidently, these tasks are closely tied to the sustainability-related research agenda.

It should be stressed that the contributions to this special issue provide examples from many parts of the word, including East and South Europe, Central and East Asia, North Africa, and Latin America (Table 1). These examples represent very different natural and cultural contexts. Therefore, the entire special issue appears to be globally representative to a certain degree, which confirms the importance of paying more attention to the natural (and not only) resources of tourism.

\section{Concluding Remarks}

This special issue achieves two general aims. First, it reveals the complexity of the nature-space-culture-tourism-sustainability nexus. Natural resources are not only geographical elements important to direct use. The contributions reveal their diverse functions. Second, this special issue demonstrates the urgency of paying close attention to tourism resources in general. In addition to natural resources, the other broad categories are cultural (also historical) and resort (also balneological) resources, and their distinction from natural resources is not always strict (transitional categories can be outlined). These meanings emphasize the importance of multidisciplinary approaches in tourism studies, where geographical, biological, and other analytical tools should not be abandoned.

Indeed, no special issue addressing so diverse and complex questions can pretend to be really comprehensive. For instance, there are some other topics which could also be considered in the context of this special issue. They include, for instance, wildlife resources [23], cross-border natural resources management for the purpose of tourism [24], food-environment-hospitality relationships [25], environmental state of important touristic locations and geographical domains [26-28], and the state governance of nature-based tourism [29]. Nonetheless, it is hoped that the present special will lead to further research in these and other topics within the resource frame.

Funding: This research received no external funding.

Institutional Review Board Statement: Not applicable.

Informed Consent Statement: Not applicable.

Data Availability Statement: Not applicable.

Acknowledgments: I am grateful for the opportunity to edit this special issue for "Sustainability". To achieve this challenging task would not have been possible without the support of the MDPI's editorial team and, particularly, Allie Shi, nor without the enthusiastic work of many experts who agreed to serve as reviewers. All scientists who contributed to this special issue are specially acknowledged. I deeply thank the administration of the K.G. Razumovsky Moscow State University of Technologies and Management (the First Cossack University) (Moscow, Russia), under whose 'umbrella' I have been able to accomplish this project.

Conflicts of Interest: The author declares no conflict of interest.

\section{References}

1. Butowski, L. Tourism as a discipline in light of the non-classical sociology of science. J. Tour. Cult. Chang. 2018, 16, 436-454. [CrossRef]

2. Cohen, E.; Cohen, S.A. Current sociological theories and issues in tourism. Ann. Tour. Res. 2012, 39, 2177-2202. [CrossRef]

3. Cohen, S.A.; Cohen, E. New directions in the sociology of tourism. Curr. Issues Tour. 2019, 22, 153-172. [CrossRef]

4. Dann, G.; Cohen, E. Sociology and tourism. Ann. Tour. Res. 1991, 18, 155-169. [CrossRef]

5. Greenblat, C.S.; Gagnon, J.H. Temporary strangers: Travel and Tourism from a Sociological Perspective. Sociol. Perspect. 1983, 26, 89-110. [CrossRef]

6. Akram, S.; Sultana, N.; Sultana, T.; Majeed, M.; Saeed, R. Country governance, tourism and environment quality: An emerging economy perspective. Manag. Sci. Lett. 2021, 11, 1737-1746. [CrossRef] 
7. Butler, R.W. Tourism, Environment, and Sustainable Development. Environ. Conserv. 1991, 18, 201-209. [CrossRef]

8. Butler, R. Sustainable tourism in sensitive environments: AWolf in sheep's clothing? Sustainability 2018, 10, 1789. [CrossRef]

9. Kousis, M. Tourism and the environment: A social movements perspective. Ann. Tour. Res. 2000, 27, 468-489. [CrossRef]

10. Marsiglio, S. Economic growth and environment: Tourism as a trigger for green growth. Tour. Econ. 2015, 21, 183-204. [CrossRef]

11. Cobos, A.; Alcalá, L. Palaeontological Heritage as a Resource for Promoting Geotourism in the Rural Setting: El Castellar (Teruel, Spain). Geoheritage 2018, 10, 405-414. [CrossRef]

12. Dowling, R.K. Geotourism's Global Growth. Geoheritage 2011, 3, 1-13. [CrossRef]

13. Hose, T.A. 3G's for Modern Geotourism. Geoheritage 2012, 4, 7-24. [CrossRef]

14. Ehsan, S.; Shafeealeman, M.; Arabegum, R. Geotourism: A tool for sustainable development of geoheritage resources. Adv. Mater. Res. 2013, 622, 1711-1715. [CrossRef]

15. Farsani, N.T.; Coelho, C.; Costa, C. Geotourism and geoparks as novel strategies for socio-economic development in rural areas. Int. J. Tour. Res. 2011, 13, 68-81. [CrossRef]

16. Kubalíková, L. Assessing geotourism resources on a local level: A case study from Southern Moravia (Czech Republic). Resources 2019, 8, 150. [CrossRef]

17. Ruban, D.A. Geotourism-A geographical review of the literature. Tour. Manag. Perspect. 2015, 15, 1-15. [CrossRef]

18. de la Cruz del Río-Rama, M.; Maldonado-Erazo, C.P.; Álvarez-García, J.; Durán-Sánchez, A. Cultural and natural resources in tourism Island: Bibliometric mapping. Sustainability 2020, 12, 724. [CrossRef]

19. Ivlieva, O.V.; Shmytkova, A.V.; Sukhov, R.I.; Kushnir, K.V.; Grigorenko, T.N. Assessing the tourist and recreational potential in the South of Russia. E3S Web Conf. 2020, 208, 05013. [CrossRef]

20. Marczak, M.; Borzyszkowski, J. Are natural resources important elements in the national tourism policy? Examples of European Countries. J. Environ. Manag. Tour. 2020, 11, 1200-1214. [CrossRef]

21. Pessot, E.; Spoladore, D.; Zangiacomi, A.; Sacco, M. Natural resources in health tourism: A systematic literature review. Sustainability 2021, 13, 2661. [CrossRef]

22. Yuxia, Y. Development of natural ecological resources and the practice of building tourism brand. J. Environ. Prot. Ecol. 2020, 21, 1386-1392.

23. Moore, S.A.; Rodger, K. Wildlife tourism as a common pool resource issue: Enabling conditions for sustainability governance. $J$. Sustain. Tour. 2010, 18, 831-844. [CrossRef]

24. Kropinova, E. Transnational and cross-border cooperation for sustainable tourism development in the Baltic sea region. Sustainability 2021, 13, 2111. [CrossRef]

25. Filimonau, V.; Ermolaev, V.A. A sleeping giant? Food waste in the foodservice of Russia. J. Clean. Prod. 2021, 297, 126705. [CrossRef]

26. Mikhailenko, A.V.; Ruban, D.A.; Ermolaev, V.A.; van Loon, A.J. Cadmium Pollution in the Tourism Environment: A Literature Review. Geosciences 2020, 10, 242. [CrossRef]

27. Hinestroza-Mena, K.M.; Toro 3, V.G.; Londoño-Colorado, G.S.; Chávez, V.; García-Blanco, J.K.; Silva, R. Fine Spatial Scale, Frequent Morphological Monitoring of Urbanised Beaches to Improve Coastal Management. J. Mar. Sci. Eng. 2021, 9, 550. [CrossRef]

28. Varenik, A.V.; Kalinskaya, D.V. The Effect of Dust Transport on the Concentration of Chlorophyll-A in the Surface Layer of the Black Sea. Appl. Sci. 2021, 11, 4692. [CrossRef]

29. Nikolskaya, E.Y.; Romanova, M.M.; Pasko, O.V.; Uspenskaya, M.E.; Saadulaeva, T.A. Formulation of development strategy for tourism and hospitality industry. Int. J. Manag. 2020, 11, 467-474. 